\title{
KOMPETENSI WIRAUSAHA, PEMBINAAN, SERTA LOKASI USAHA PENGARUHNYA TERHADAP KESUKSESAN BERWIRAUSAHA BAGI PELAKU USAHA SKALA MIKRO
}

\author{
${ }^{1}$ Muhamad Rifa'i, \\ Fakultas Ekonomi Universitas Tribhuwana Tunggadewi \\ Email: rifaiunitri@gmail.com \\ ${ }^{2}$ Suprihatin, \\ Fakultas Ekonomi Universitas Tribhuwana Tunggadewi \\ Email: suprikayong@gmail.com; \\ ${ }^{3}$ Warter Agustim \\ Fakultas Ekonomi Universitas Tribhuwana Tunggadewi \\ Email: warteragustim@gmail.com
}

\begin{abstract}
Success in conducting business activities carried out by small businesses often faced with the many issues faced. These obstacles often make small businesses difficult to develop. This research aims to describe the influence of entrepreneurial competency, coaching and business location to the success of entrepreneurial in small business traders located in the village of Tlogomas Malang. The approach used is quantitative. The results of the study showed that competence has no significant effect on successful business. Coaching variables influence positively but also insignificant to business success. While the location of business affects positively and significantly to the success of the business, but simultaneously competence, coaching, and business locations influence positive and significant to the success of the business.
\end{abstract}

Keywords: Entrepreneurial Competence, Coaching, Business Location, Success

\begin{abstract}
ABSTRAK
Kesuksesan dalam menjalankan kegiatan usaha yang dilakukan oleh para pelaku usaha kecil sering kali dihadapkan banyaknya persoalan yang dihadapi. Kendala tersebut sering menjadikan para pelaku usaha kecil kesulitan untuk bisa berkembang. Penelitian ini bertujuan untuk mendiskripsikan pengaruh kompetensi wirausaha, pembinaan dan lokasi usaha terhadap kesuksesan berwirausaha pada pedagang usaha kecil yang berlokasi di kelurahan Tlogomas kota Malang. Pendekatan penelitian yang digunakan adalah kuantitatif. Hasil penelitian menujukan kompetensi tidak berpengaruh signifikan terhadap kesuksesan usaha. Variabel pembinaan berpengaruh secara positif tetapi juga tidak signifikan terhadap kesuksesan usaha. Sedangkan lokasi usaha berpengaruh secara positif dan signifikan terhadap kesuksesan usaha, namun secara simultan kompetensi, pembinaan, dan lokasi usaha berpengaruh positif dan signifikan terhadap kesuksesan usaha.
\end{abstract}

Kata kunci: Kompetensi Wirausaha, Pembinaan, Lokasi Usaha, Kesuksesan

\section{PENDAHULUAN}

Kewirausahaan saat ini memiliki peran sangat penting untuk mendorong bagi pertumbuhan perekonomian nasional, selain menjadi suatu penopang untuk mendorong 
kemajuan ekonomi masyarakat yang lebih baik, dengan adanya wirausaha akan memberi banyak manfaat baik untuk masyarakat maupun negara seperti menaikkan taraf hidup masyarakat, mengurangi tingkat pengangguran, mengurangi kriminalitas, penyaluran pendapatan masyarakat yang lebih merata, serta potensi penerimaan pajak bagi pemerintah. Keberadaan wirausaha juga bertindak sebagai agen perubahan, membawa ide-ide untuk pasar, serta mendorong pertumbuhan ekonomi karena terdapat kecenderungan untuk selalu berinovasi. Wirausaha selama ini terbukti mampu menggerakkan perekonomian masyarakat melalui penciptaan lapangan kerja dan memberikan banyak pemasukan terhadap negara dari sektor pajak (Sayekti, 2016). Peran serta fungsi wirausaha ini sebenarnya juga bisa ditingkatkan dengan menggunakan wirausaha sebagai suatu pelaku usaha pelengkap untuk pengembangan perekonomian nasional. Menurut Kasali (2005) terdapat lima alasan utama diperlukannya pengembangan kewirausahaan, yaitu: (1) mendorong pertumbuhan ekonomi dan pembukaan lapangan kerja baru, (2) melahirkan kreativitas dan inovasi baru dalam melakukan usaha, (3) dapat meningkatkan kualitas kompetisi yang berujung pada nilai tambah bagi masyarakat, (4) dapat menurunkan biaya dan waktu yang timbul akibat ketidakpastian dan (5) kesejahteraan masyarakat dapat dilakukan melalui created wealth, bukan inherited wealth .

Saat ini meskipun telah banyak tumbuh ditengah-tengah masyarakat, namun secara umum wirausaha di Indonesia belum bisa berkembang dengan baik, khususnya usaha skala kecil (mikro) karena masih banyak hambatan yang dihadapi. Hambatanhanbatan tersebut membuat pelaku usaha sulit mengembangkan usaha yang dijalankanya serta sulit untuk bisa bersaing. Menurut Beck (2007) yang menyatakan bahwa usaha kecil dan menengah yang baru untuk tumbuh sangat penting untuk memperhatikan faktor lingkungan bisnis internal maupun eksternal. Salah satu bentuk hambatan tersebut adalah kemampuan kepemilikan sumberdaya manusia atau kompetensi dibidang usahanya, kurang sesuainya pemilihan lokasi usaha, kesulitan dalam melakukan pemasaran, kesulitan mendapatkan modal, kurangnya inovasi produk, keterbatasan bahan baku dan teknologi serta masih banyak lagi yang membuat hambatan bagi wirausaha untuk mencapai kesuksesan dalam mengelola usahanya. Menurut Meydianawathi (2011) Sektor formal dan informal dibedakan berdasarkan ciri pekerjaan mereka dan pengarahan tenaga kerja. 
Salah satu hambatan yang sering dihadapi dalam menjalankan usaha khususnya usaha skala kecil adalah kompetensi wirausaha. Kurniawan (2018) dalam studinya menjelaskan bahwa terdapat pengaruh positif variabel kompetensi kewirausahaan dan kelanggengan usaha terhadap keunggulan bersaing usaha. Sementara itu Fithri dan Amanda (2012) menjelaskan bahwa kompetensi memiliki arti sebagai pengetahuan, keterampilan dan kemampuan individu yang langsung berpengaruh pada kinerja dalam mengembangkan usaha atau karirnya. Selain itu yang perlu diperhatikan adalah pembinaan wirausaha juga diperlukan untuk pengembangan suatu usaha. Peraturan Pemerintah Nomor 32 tahun 1998 tentang Pembinaan dan Pengembangan Usaha Kecil menjelaskan bahwa Pembinaan usaha merupakan upaya yang dilakukan oleh pemerintah, dunia usaha serta masyarakat melalui pemberian bimbingan dan bantuan perkuatan untuk menumbuhkan dan meningkatkan kemampuan usaha kecil agar menjadi usaha yang tangguh dan mandiri serta dapat berkembang menjadi usaha menengah. Dalam peraturan tersebut diatur mengenai beberapa hal, yaitu pembinaan usaha kecil yang dilaksanakan oleh dunia usaha dan masyarakat berupa: (1) penyediaan tenaga konsultan profesional, sarana, prasarana, teknologi, dana dan informasi, (2) bimbingan dan konsultan, (3) pendidikan dan pelatihan, serta (4) pendirian klinik konsultasi bisnis untuk usaha kecil.

Selain itu yang tidak kalah penting dalam pengembangan suatu usaha adalah masalah lokasi usaha juga sangat penting untuk diperhatikan. Lokasi sangat berkaitan dengan saluran pemasaran antara tempat dan keputusan saluran distribusi. Menurut Tjiptono (2015) menjelaskan tempat adalah keputusan distribusi yang menyangkut kemudahan akses terhadap jasa bagi para pelanggan potensial. Lupiyoadi (2013:96) menjelaskan bahwa lokasi berhubungan dengan di mana usaha harus didirikan dan melakukan operasi atau kegiatannya. Menurut Ekasari (2018) terdapat beberapa faktor yang perlu dipertimbangkan secara cermat dalam pemilihan lokasi usaha yaitu: (1) aksesivisibilitas lokasi yang dapat dilihat dengan jelas dari tepi jalan; (2) lalu lintas (traffic), (3) keamanan, (4) lingkungan sekitar yang mendukung produk yang ditawarkan, (5) tingkat persaingan, serta (6) peraturan pemerintah.

Saat ini kota Malang memiliki banyak potensi dalam bidang wirausaha dari usaha kecil menengah maupun usaha dalam skala besar. Baik dari bidang usaha budaya, pariwisata, serta dibidang kuliner. Berdasarkan data hasil survey Dinas koperasi tahun 
2009, jumlah usaha kecil dan menengah di Kota Malang mencapai 800 unit yang tersebar pada lima kecamatan, namun sampai saat ini masih banyak terdapat usaha kecil yang belum terdata pada pemerintah kota Malang. Salah satu daerah di kota Malang yang memiliki banyak pelaku wirausahawan yaitu di terletak kelurahan Tlogomas Kecamatan Lowokwaru kota Malang, karena banyak dikelilingi perguruan tinggi yang memiliki berbagai jenis potensi bidang usaha yang bisa dikembangkan oleh masyarakat setempat seperti dibidang kerajinan, olahan pangan, perdagangan serta berbagai jenis jasa lainya.

Sekala usaha yang mendominasi di wilayah tersebut adalah usaha kecil dan menengah, jasa, serta perdagangan, diamana salah satunya yang paling banyak adalah berdagang di bidang kuliner dengan membuka warung maupun dijual secara berkeliling dengan media gerobak. Salah satu usaha kuliner yang banyak berkembang saat ini adalah pedagang nasi goreng keliling yang banyak berjualan, kegiatan usaha menjual nasi goreng di wilayah Tlogomas sangat menjanjikan karena mudah dalam mencari konsumen yang mayoritas para mahasiswa yang sedang menempuh pendidikan dan yang tinggal di wilayah tersebut. Selain itu juga diuntungkan dengan media gerobak yang mudah untuk masuk kedalam gang tempat tinggal konsumen sehingga penjualan lebih maksimal. Dengan peluang usaha yang ada, para pedagang nasigoreng keliling harus memiliki kompetensi dalam berwira usaha serta tepat dalam memilih lokasi berjualan, agar dapat memaksimalkan peluang usaha yang mereka tekuni sehingga usahanya berkembang dan mencapai kesuksesan. Serta dibutuhkan pula peran pemerintah dalam melakukan pembinaan usaha sehingga dapat mengarahkan atau membantu pedagang dalam menjalankan usaha maupun memecahkan masalah yang ada. Dari beberapa hambatan yang membuat kegiatan usaha mereka tidak berkembang adalah kurangnya kompetensi dalam biudang wirausaha, kurangnya pembinaan dari pihak-pihak terkait, serta pemilihan lokasi usaha yang tidak tepat karena banyaknya pesaing yang menjual produk yang sama di lokasi yang berdekatan.

\section{LANDASAN TEORI}

Kompetensi wirausaha sangat diperlukan dalam suatu kegiatan usaha, Christiana (2014:74) menjelaskan wirausaha adalah seseorang yang menciptakan bisnis baru dengan mengambil risiko dan ketidak pastian demi mencapai keuntungan dan 
pertumbuhan dengan cara mengidetifikasi peluang dan menggabungkan sumber daya yang diperlukan untuk mendirikannya. Menutut Busro (2018:26) kompetensi usaha adalah kemampuan dan pengetahuan manusia, khususnya kemampuan untuk berbagai kebutuhan dalam bisnis dengan meminimalkan biaya dan memaksimalkan pelayanan kepada pelanggan secara lebih. Sementara itu, Fithri dan Amanda (2012:280) kompetensi memiliki arti sebagai pengetahuan, keterampilan dan kemampuan individu yang langsung berpengaruh pada kinerja dalam mengembangkan usaha atau karirnya. Suryana (2006:88) mengungkapkan bahwa kompetensi atau kemampuan yang harus dimiliki oleh wirausaha tersebut secara riil tercermin melalui: (1) Kemampuan dan kemauan untuk memulai usaha (start up), (2) Kemampuan untuk mengerjakan sesuatu yang baru (creative), (3) Kemauan dan kemampuan untuk mencari peluang (opportunity), dan (4) Kemampuan dan keberanian untuk menanggung risiko (risk bearing).

Selain kompetensi wirausaha pembinaan juga merupakan hal penting bagi pelaku usaha, Dongoran (2016), Pembinaan adalah proses mengajarkan keahlian atau ketreampilan dan memberikan pengetahuan yang perlu serta sikap supaya mereka dapat melaksanakan tanggung jawabnya sesuai dengan standar yang telah ditentukan. Sedangkan menurut Alhempi dan Raden, (2013), pembinaan adalah suatu proses atau pengembangan yang mencakup urut-urutan pengertian, diawali dengan mendirikan, menumbuhkan, memelihara pertumbuhan tersebut yang disertai usaha-usaha perbaikan, menyempurnakan dan mengembangkannya. Manfaat dan tujuan pembinaan menurut Hamalik, (2000:14) menyatakan jika pembinaan dilakukan terus menerus diharapkan pengusaha dan pengrajin akan menjadi lebih baik dan lebih sesuai dengan budaya yang digunakan dalam organisasi, seperti bekerja keras, bekerja dengan baik, mempunyai semangat yang tinggi, memiliki mental yang kuat, mempunyai rasa kepedulian yang tinggi terhadap prestasi.

Selain itu lokasi usaha juga merupakan faktor penting yang harus diperhatikan dalam melaksanakan kegiatan usaha, menurut Maskan (2018:40) lokasi memiliki peranan penting di dalam menjalankan usaha karena lokasi usaha sangat berkaitan dengan dekatnya pusat keramaiaan, mudah di jangkau, aman, dan tersedianya tempat parkir, sehingga pada umumnya di sukai oleh konsumen. Lokasi berkaitan dengan saluran pemasaran antara tempat dan keputusan saluran distribusi. Menurut Fu'ad 
(2015), place adalah keputusan distribusi yang menyangkut kemudahan akses terhadap jasa bagi para pelanggan potensial. Lupiyoadi (2013:96) menjelaskan bahwa lokasi berarti berhubungan dengan di mana usaha harus bermarkas dan melakukan operasi atau kegiatannya.

Kesuksesan usaha dalah suatu pencapaian yang menjadi salah satu tujuan utama dari bentuk usaha apapun. Menurut Suyatno (2010:179) Usaha kecil dikatakan mencapai kesuksesan apabila maksud dan tujuan dari usaha tersebut sudah tercapai sesuai yang diharapkan. Sebagai ukuran keberhasilan usaha suatu perusahaan dapat dilihat dari berbagai aspek, seperti: kinerja keuangan dan image perusahaan. Seperti yang dikemukakan oleh Suryana (2011:66) bahwa Untuk menjadi wirausaha yang sukses harus memiliki ide atau visi bisnis yang jelas, kemudian ada kemauan dan keberanian untuk menghadapi resiko baik waktu maupun uang. Erliah (2007:49) mengatakan bahwa suatu usaha dikatakan berhasil di dalam usahanya apabila setelah jangka waktu tertentu usaha tersebut mengalami peningkatan baik dalam permodalan, skala usaha, hasil atau laba, jenis usaha atau pengelolaan. Sedangkan menurut Kasmir (2006:27) sebuah perusahaan dikatakan meraih keberhasilan atau kesuksesan usaha jika usaha: (1) Penghasilan atau pendapatan usahanya bertambah, (2) Tingkat produksi meningkat, (3) tingkat laba bertambah, (4) Adanya kepuasan pelanggan, (5) Mutu produk baik, dan (6) Usahanya berkembang dan penghasilan karyawan dari perusahaan tersebut bertambah.

Gambar 1. kerangka penelitian

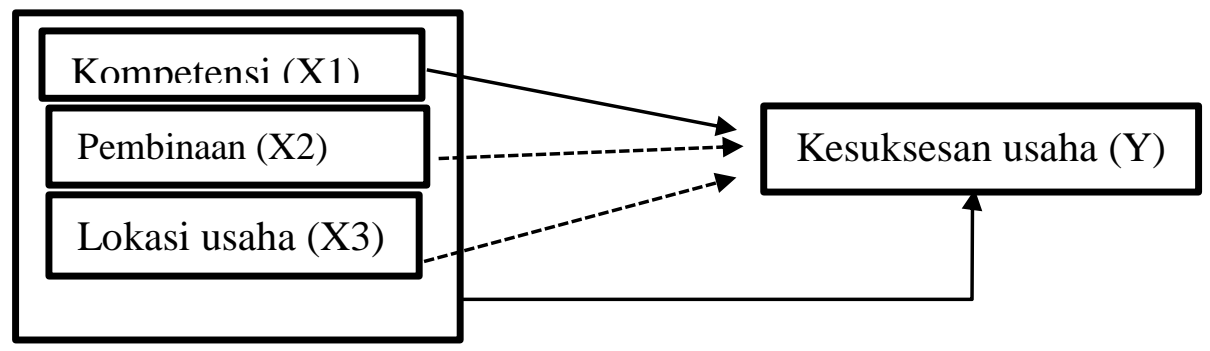

Hipotesis dalam penelitian ini:

H1. Kompetensi berpengaruh secara signifikan terhadap kesuksesan usaha.

H2. Pembinaan berpengaruh secara signifikan terhadap kesuksesan usaha.

H3. Lokasi usaha berpengaruh secara signifikan terhadap kesuksesan usaha. 
H4. kompetensi, pembinaan dan lokasi usaha berpengaruh secara positif dan simultan terhadap kesuksesan usaha.

\section{METODE PENELITIAN}

Dalam penelitian ini peneliti menggunakan pendekatan penelitian kuantitatif. Adapun populasi pada penelitian ini adalah pelaku usaha mikro yang berusaha dalam kegiatan pedagang nasi goreng keliling di wilayah kelurahan Tlogomas kota Malang. Tehnik sampling pada penelitian ini menggunakan sampel sensus dikarenakan jumlah populasinya tidak lebih besar dari 100 orang, maka peneliti mengambil seluruh populasi yang ada pada pedagang nasi goreng di kawasan Tlogomas kota Malang sebagai sampel, yaitu sebanyak 37 orang responden. Variabel yang digunakan dalam penelitian ini adalah untuk menguji pengaruh variabel kompetensi wirausaha, pembinaan dan lokasi usaha terhadap kesuksesan usaha. Data penelitian dikumpulkan melalui kegaiatan observasi, wawancara, dokumentasi, serta penyebaran kuesioner. Skala yang digunakan adalah skala Likert dengan lima alternatif jawaban responden. Sebelum digunakan untuk mengumpulkan data dari responden, instrumen penelitian diujicobakan terlebih dahulu dan hasilnya dilakukan uji validitas dan reliabilitas. Teknik analisis data penelitiaan menggunakan analisis deskriptif dan analisis regresi linear berganda. Pengujian asumsi klasik dilakukan sebelum dilakukan analisis data dengan analisis regresi berganda yang dirumuskan sebagai berikut: $\boldsymbol{Y}=\boldsymbol{a}+\boldsymbol{b}_{\mathbf{1}} \boldsymbol{x}_{\mathbf{1}}+\boldsymbol{b}_{\mathbf{2}} \boldsymbol{x}_{\mathbf{2}} \pm \boldsymbol{b}_{\mathbf{3}} \boldsymbol{x}_{\mathbf{3}}+\mathbf{e}$ Dimana: $\mathrm{Y}=$ kesuksesan usaha, $x_{1}=$ Kompetensi, $x_{2}=$ Pembinaan, $x_{3}=$ lokasi usaha, $a$ $=$ konstanta, $b=$ koefisien regresi, $e=$ error. Untuk menguji hipotesis penelitian maka menggunakan uji $\mathrm{t}$ dan uji f untuk uji hipotesis baik secara parsial maupun secara simultan.

\section{PEMBAHASAN}

Kawasan kelurahan Tlogomas, kecamatan Lowokwaru, kota Malang, memiliki berbagai aktivitas sektor usaha guna membangun perekonomian warga di wilayah tersebut, antara lain: sektor pertanian, peternakan, industri kecil, menengah, dan besar, bidang jasa serta perdagangan. Hasil distribusi frekuensi dari 37 pedagang nasi goreng dikawasan kelurahan Tlogomas kota Malang yang dijadikan sebagai responden dalam penelitian ini dapat dilihat mengenai item dari variabel penelitian. Hasil analisis deskripsi Variabel Kompetensi disajikan dalam tabel 1 sebagai berikut: 
Tabel 1. Deskripsi Jawaban Responden variabel kompetensi.

\begin{tabular}{|c|c|c|c|c|c|c|c|c|c|c|c|c|}
\hline \multirow{2}{*}{ No } & \multirow{2}{*}{ Item } & \multicolumn{2}{|c|}{ STS } & \multicolumn{2}{|c|}{ TS } & \multicolumn{2}{|c|}{$\mathrm{N}$} & \multirow{2}{*}{$\frac{\mathrm{S}}{\mathrm{n}}$} & \multicolumn{3}{|c|}{ SS } & \multirow[t]{2}{*}{ Rata-rata } \\
\hline & & $\mathrm{n}$ & $\%$ & $\mathrm{n}$ & $\%$ & $\mathrm{n}$ & $\%$ & & $\%$ & $\mathrm{n}$ & $\%$ & \\
\hline 1 & $\mathrm{X} 1.1$ & 0 & 0,0 & 1 & 2,7 & 5 & 13,5 & 18 & 35,1 & 13 & 35,1 & 4,1622 \\
\hline 2 & $\mathrm{X} 1.2$ & 0 & 0,0 & 0 & 0,0 & 9 & 24,3 & 18 & 48,6 & 10 & 27,0 & 4,0270 \\
\hline 3 & X1.3 & 0 & 0,0 & 0 & 0,0 & 3 & 8,1 & 19 & 51,4 & 15 & 40,5 & 4,3243 \\
\hline 4 & $\mathrm{X} 1.4$ & 0 & 0,0 & 0 & 0,0 & 3 & 8,1 & 22 & 59,5 & 12 & 32,4 & 4,2432 \\
\hline 5 & $\mathrm{X} 15$ & 0 & 0,0 & 0 & 0,0 & 1 & 2,7 & 20 & 54,1 & 16 & 43,2 & 4,4054 \\
\hline 6 & X1.6 & 0 & 0,0 & 1 & 2,7 & 8 & 21,6 & 20 & 54,1 & 8 & 21,6 & 3,9459 \\
\hline \multicolumn{12}{|c|}{ Rata-rata/Mean kompetensi (X1) } & 4,1847 \\
\hline
\end{tabular}

Berdasarkan hasil jawaban dari responden tentang kompetensi pada tabel 1 tersebut menunjukkan bahwa nilai rata-rata dari variabel kompetensi adalah sebesar 4,18 Hal ini memberikan makna bahwa pedagang nasi goreng keliling diwilayah Kelurahan Tlogomas memberi tanggapan yang baik atas pernyataan pada kuesioner variabel kompetensi. Nilai rata-rata terbesar dari variabel kompetensi pada item pernyataan X1.5 yaitu pedagang memiliki kemampuan untuk mencari peluang usaha $(4,40)$. Rata-rata terendah yaitu sebesar 3,94 dari jawaban responden pada item pernyataan X1.6 mengenai kemampuan pedagang untuk mengambil segala resiko dari usaha yang ditekuni. Ditinjau dari rata-rata variabel kompetensi sebesar 4,18 maka dapat dinyatakan bahwa kompetensi dipersepsikan baik oleh pedagang nasi goreng keliling diwilayah Kelurahan Tlogomas Malang. Dengan kata lain pedagang menyatakan setuju bahwa kompetensi meningkatkan kesuksesan usaha.

Sedangkan untuk deskripsi jawaban rensponden terhadap variabel pembinaan dapat disajikan dalam tabel 2 sebegai berikut:

Tabel 2 Deskripsi Jawaban Responden variabel Pembinaan

\begin{tabular}{|c|c|c|c|c|c|c|c|c|c|c|c|c|}
\hline \multirow{2}{*}{ No } & \multirow{2}{*}{ Item } & \multicolumn{2}{|c|}{ STS } & \multicolumn{2}{|c|}{$\mathrm{TS}$} & \multicolumn{2}{|l|}{$\mathrm{N}$} & \multicolumn{2}{|l|}{ S } & \multicolumn{2}{|c|}{ SS } & \multirow[t]{2}{*}{ Rata-rata } \\
\hline & & $\mathrm{n}$ & $\%$ & $\mathrm{n}$ & $\%$ & $\mathrm{n}$ & $\%$ & $\mathrm{n}$ & $\%$ & $\mathrm{n}$ & $\%$ & \\
\hline 1 & $\mathrm{X} 2.1$ & 0 & 0,0 & 0 & 0,0 & 7 & 18,9 & 19 & 51,4 & 11 & 29,7 & 4,1081 \\
\hline 2 & $\mathrm{X} 2.2$ & 0 & 0,0 & 1 & 2,7 & 3 & 8,1 & 23 & 62,2 & 10 & 27,0 & 4,1351 \\
\hline 3 & $\mathrm{X} 2.3$ & 0 & 0,0 & 0 & 0,0 & 5 & 13,5 & 16 & 43,2 & 16 & 43,2 & 4,2973 \\
\hline 4 & X2.4 & 0 & 0,0 & 0 & 0,0 & 7 & 18,9 & 18 & 48,6 & 12 & 32,4 & 4,1351 \\
\hline 5 & $\mathrm{X} 2.5$ & 0 & 0,0 & 0 & 0,0 & 5 & 13,5 & 21 & 56,8 & 11 & 29,7 & 4,1622 \\
\hline 6 & X2.6 & 0 & 0,0 & 0 & 0,0 & 3 & 8,1 & 17 & 45,9 & 17 & 45,9 & 4,3784 \\
\hline \multicolumn{12}{|c|}{ Rata-rata/Mean pembinaan } & 4,2027 \\
\hline
\end{tabular}


Berdasarkan hasil jawaban dari responden tentang pembinaan pada tabel 2 tersebut menunjukkan bahwa nilai rata-rata dari variabel pembinaan adalah sebesar 4,20 Hal ini memberikan makna bahwa pedagang nasi goreng keliling diwilayah Kelurahan Tlogomas memberi tanggapan yang baik atas pernyataan pada kuesioner variabel kompetensi. Nilai rata-rata terbesar dari variabel kompetensi pada item pernyataan X2.6 yaitu adanya pemberian pelatihan usaha meningkatkan ketrampilan dalam mengembangkan usaha (4,37). Rata-rata terendah yaitu sebesar 4,10 dari jawaban responden pada item pernyataan X2.1 mengenai penyediaan sarana prasarana, tehnologi informasi membantu pedagang dalam mengembangkan usaha. Ditinjau dari rata-rata variabel Pembinaan sebesar 4,20 maka dapat dinyatakan bahwa Pembinaan dipersepsikan baik oleh pedagang nasi goreng keliling diwilayah Kelurahan Tlogomas Malang. Dengan kata lain pedagang menyatakan setuju bahwa pembinaan sangat penting untuk meningkatkan kesuksesan usaha.

Untuk hasil deskripsi dari variabel lokasi Usaha disajikan dalam tabel 3 sebagai berikut:

Tabel 3 Deskripsi Jawaban Responden variabel lokasi usaha.

\begin{tabular}{|c|c|c|c|c|c|c|c|c|c|c|c|c|}
\hline \multirow{2}{*}{ No } & \multirow{2}{*}{ Item } & \multicolumn{2}{|c|}{ STS } & \multicolumn{2}{|c|}{$\mathrm{TS}$} & \multicolumn{2}{|c|}{$\mathrm{N}$} & \multicolumn{2}{|l|}{$S$} & \multicolumn{2}{|l|}{ SS } & \multirow[t]{2}{*}{ Rata-rata } \\
\hline & & $\mathrm{n}$ & $\%$ & $\mathrm{n}$ & $\%$ & $\mathrm{n}$ & $\%$ & $\mathrm{n}$ & $\%$ & $\mathrm{n}$ & $\%$ & \\
\hline 1 & X3.1 & 0 & 0,0 & 0 & 0,0 & 3 & 8,1 & 19 & 51,4 & 15 & 40,5 & 4,3243 \\
\hline 2 & X3.2 & 0 & 0,0 & 0 & 0,0 & 4 & 10,8 & 25 & 67,6 & 8 & 21,6 & 4,1081 \\
\hline 3 & X3.3 & 0 & 0,0 & 0 & 0,0 & 2 & 5,4 & 24 & 64,9 & 11 & 29,7 & 4,2432 \\
\hline 4 & X3.4 & 0 & 0,0 & 0 & 0,0 & 2 & 5,4 & 28 & 75,7 & 7 & 18,9 & 4,1351 \\
\hline 5 & $\mathrm{X} 3.5$ & 0 & 0,0 & 0 & 0,0 & 2 & 5,4 & 23 & 62,2 & 12 & 32,4 & 4,2703 \\
\hline 6 & X3.6 & 0 & 0,0 & 0 & 0,0 & 2 & 5,4 & 26 & 70,3 & 9 & 24,3 & 4,1892 \\
\hline 7 & X3.7 & 0 & 0,0 & 0 & 0,0 & 6 & 16,2 & 17 & 45,9 & 14 & 37,8 & 4,2162 \\
\hline Rata & $\mathrm{ta} / \mathrm{Me}$ & lok & usal & & & & & & & & & 4,2123 \\
\hline
\end{tabular}

Sumber: Data Primer diolah, 2019

Nilai rata-rata terbesar dari variabel Lokasi usaha pada item pernyataan X3.1 yaitu lokasi usaha mudah dijangkau atau dilalui jalur transportasi $(4,32)$. Rata-rata terendah yaitu sebesar 4,10 dari jawaban responden pada item pernyataan X3.2 mengenai lokasi usaha tidak berada di area lokasi kemacetan lalulintas. Ditinjau dari rata-rata total variabel Pembinaan sebesar 4,21 maka dapat dinyatakan bahwa lokasi usaha dipersepsikan baik oleh pedagang nasi goreng keliling diwilayah Kelurahan 
Tlogomas Malang. Dengan kata lain pedagang menyatakan setuju bahwa lokasi usaha adalah salah satu faktor untuk meningkatkan kesuksesan usaha.

Sedangkan tabel 4 tentang menujukan deskripsi jawaban responden berdasarkan peryataan pada kuesioner dalam variabel Kesuksesan Usaha

Tabel 4. Deskripsi Jawaban Responden variabel Kesuksesan Usaha

\begin{tabular}{|c|c|c|c|c|c|c|c|c|c|c|c|c|}
\hline \multirow{2}{*}{ No } & \multirow{2}{*}{ Item } & \multicolumn{2}{|c|}{ STS } & \multicolumn{2}{|c|}{$\mathrm{TS}$} & \multicolumn{2}{|c|}{$\mathrm{N}$} & \multicolumn{2}{|l|}{$\mathrm{S}$} & \multicolumn{2}{|l|}{ SS } & \multirow[t]{2}{*}{ Rata-rata } \\
\hline & & $\mathrm{n}$ & $\%$ & $\mathrm{n}$ & $\%$ & $\mathrm{n}$ & $\%$ & $\mathrm{n}$ & $\%$ & $\mathrm{n}$ & $\%$ & \\
\hline 1 & Y.1 & 0 & 0,0 & 0 & 0,0 & 5 & 13,5 & 17 & 45,9 & 15 & 40,5 & 4,2703 \\
\hline 2 & Y.2 & 0 & 0,0 & 0 & 0,0 & 6 & 16,2 & 17 & 45,9 & 14 & 37,8 & 4,2162 \\
\hline 3 & Y.3 & 0 & 0,0 & 0 & 0,0 & 7 & 18,9 & 13 & 35,1 & 17 & 45,9 & 4,2703 \\
\hline 4 & Y.4 & 0 & 0,0 & 0 & 0,0 & 5 & 13,5 & 12 & 32,4 & 20 & 54,1 & 4,4054 \\
\hline 5 & Y.5 & 0 & 0,0 & 0 & 0,0 & 9 & 24,3 & 9 & 24,3 & 19 & 51,4 & 4,2703 \\
\hline 6 & Y.6 & 0 & 0,0 & 0 & 0,0 & 8 & 21,6 & 14 & 37,8 & 15 & 40,5 & 4,1892 \\
\hline
\end{tabular}

Sumber: Data Primer diolah, 2019

Berdasarkan hasil jawaban dari responden tentang Kesuksesan Usaha (Y) pada tabel 4.6 tersebut menunjukkan bahwa nilai rata-rata terbesar $(4,40)$ adalah pada item Y4 mengenai pelanggan telah merasa puas dengan produk yang pedagang jual. Ratarata terendah dalah pada item Y.6 mengenai pedagang merasa usaha yang ditekuni telah mengalami perkembangan. Dengan rata-rata total kesuksesan usaha sebesar 4,27.

Hasil pengujian dengan analisis Regresi Linear Berganda menujukkan hasil sebagai berikut:

Tabel 7. Hasil Analisis Regresi Linier berganda

\begin{tabular}{|c|c|c|c|c|c|}
\hline Variabel & $\begin{array}{l}\text { Unstandardized } \\
\text { Coefficients (B) }\end{array}$ & $\begin{array}{l}\text { Std. } \\
\text { eror }\end{array}$ & $\begin{array}{c}\text { Standardized } \\
\text { Coefficients (Beta) }\end{array}$ & t hitung & Sig \\
\hline Konstanta & 15,999 & 8.833 & & 1,811 & 0,079 \\
\hline$(\mathrm{X} 1)$ & $-0,424$ & 0,240 & 0,351 & $-1,767$ & 0,086 \\
\hline (X2) & 0,080 & 0,209 & 0,518 & ,381 & 0,705 \\
\hline (X3) & 0,620 & 0,215 & 0,507 & 2,882 & 0,007 \\
\hline
\end{tabular}

Sumber data: Data primeryang diolah 2019

Dari hasil analisis pada tabel 4.11 dapat dibuat persamaan regresi linear berganda sebagai berikut: $Y=15,99+-0,424+0,080+0,620+8,833$, persamaan regresi tersebut dapat dijelaskan: bo $=15,999$, dimana nilai konstanta ini menunjukkan bahwa jika tidak ada kompetensi, pembinaan dan lokasi usaha $(\mathrm{X} 1, \mathrm{X} 2, \mathrm{X} 3)$ maka nilai 
konsisten kesuksesan usaha (Y) adalah sebesar 15,999. Sedangkan $b_{1}=-0,424$, yaitu nilai parameter atau koefisien regresi $b_{1}$ ini menunjukkan bahwa setiap penambahan $1 \%$ tingkat Kompetensi (X1) maka kesuksesan usaha (Y) akan meningkat sebesar -0,424. Karena nilai koefisien regresi bernilai minus (-), maka dengan demikian dapat dikatakan bahwa Kompetensi (X1) berpengaruh negatif terhadap kesuksesan usaha (Y), serta tidak signifikan nilai signifikan (sig.) kompetensi (X1) $0,086>$ probabilitas 0,05 . Untuk $\mathrm{b}_{2}=$ 0.080, yaitu nilai parameter atau koefisien regresi $b_{2}$ ini menunjukkan bahwa setiap penambahan $1 \%$ tingkat Pembinaan (X2) maka kesuksesan usaha (Y) akan meningkat sebesar 0.080. Karena nilai koefisien regresi bernilai plus (+), maka dengan demikian dapat dikatakan bahwa Pembinaan (X2) berpengaruh Positif terhadap kesuksesan usaha (Y), serta tidak signifikan karena nilai signifikan (sig.) Pembinaan (X2) 0,705 > probabilitas 0,05 . Dan $b_{3}=0,620$, menujukkan nilai parameter atau koefisien regresi $b_{3}$ ini menunjukkan bahwa setiap penambahan 1\% tingkat lokasi usaha (X3) maka kesuksesan usaha (Y) akan meningkat sebesar 0.620. Karena nilai koefisien regresi bernilai minus (+), maka dengan demikian dapat dikatakan bahwa Pembinaan (X3) berpengaruh Positif terhadap kesuksesan usaha (Y), serta signifikan karena nilai signifikan (sig.) lokasi usaha (X3) 0,007 > probabilitas 0,05.

\section{Pengaruh Kompetensi Usaha Terhadap Kesuksesan Usaha.}

Hasil penelitian menunjukkan bahwa kompetensi tidak berpengaruh signifikan terhadap kesuksesan usaha, yang terlihat dari nilai sig untuk kompetensi adalah 0,086. Nilai sig lebih besar dari nilai probabilitas 0,05 , atau 0,086>0,05 artinya variabel kompetensi tidak memiliki kontribusi terhadap kesuksesan berwirausaha. Hasil ini terjadi karena tidak selalu kompetensi berpengaruh signifikan terhadap kesuksesan usaha pada pedagang nasi goreng keliling diwilayah kelurahan Tlogomas kota Malang, ada faktor pendukung lain yang mempengaruhi kesuksesan usaha baik faktor internal maupun eksternal, untuk pengaruh internal yang dapat mempengaruhi kesuksesan usaha seperti memelihara norma kejujuran, bertanggung jawab atas kinerja pribadi, keluwesan dalam menghadapi perubahan, terbuka terhadap informasi-informasi baru, motivasi, komitmen, pengalaman, juga optimis dalam menghadapi halangan dan kegagalan. Untuk faktor eksternal yang mempengaruhi kesuksesan usaha yaitu, peluang pasar yang baik yaitu mendukung terhadap produk yang di jual, budaya, kualitas produk yang baik, 
keunggulan persaingan, lingkungan usaha atau lokasi usaha yang strategis, serta dukungan modal dari pemerintah maupun yang lain. Hasil penelitian ini mendukung penelitian terdahulu oleh Pamela, Rachmat Pambudy, dan Ratna Winandi (2016) tentang Pengruh Kompetensi Kewirausahaan Dengan Keberhasilan Usaha Peternak Sapi Perah Pujon, Malang. Dengan hasil Kompetensi kewirausahaan memiliki pengaruh negatif dan tidak signifikan terhadap keberhasilan usaha

\section{Pengaruh Pembinaan Usaha Terhadap Kesuksesan Usaha.}

Hasil penelitian menunjukan bahwa secara parsial pembinaan tidak berpengaruh signifikan terhadap kesuksesan usaha, Hal ini dapat terjadi karena kurangnya tingkat pembinaan yang diberikan oleh pihak terkait terhadap wirausaha kususnya pedagang nasi goreng keliling diwilayah Tlogomas kota malang, sehingga pembinaan hanya memberi sedikit peran terhadap pedagang didalam mencapai kesuksesan usaha, pihak terkait harus memberikan kontribusi lebih dalam hal pembinaan agar dapat memberikan dampak yang lebih positif dan signifikan kepada pedagang nasi goreng keliling diwilayah Kelurahan Tlogomas Malang dengan harapan semakin baik pembinaan usaha akan meningkatkan kesuksesan usaha pada pedagang nasi goreng keliling di wilayah Tlogomas kota Malang. Dari hasil penelitian ini tidak sejalan dengan peneliti terdahulu, oleh Rina Irawati (2018) Pengaruh Pelatihan Dan Pembinaan Terhadap Pengembangan Usaha Kecil, pada UKM disepanjang panati Baron Jogja dengan hasil, ada pengaruh secara parsial pembinaan terhadap pengembangan usaha kecil.

\section{Pengaruh Lokasi Usaha Terhadap Kesuksesan Usaha.}

Hasil penelitian menunjukan bahwa secara parsial lokasi usaha berpengaruh signifikan terhadap kesuksesan usaha pada pedagang nasi goreng keliling di Kawasan Tlogo Mas Malang. Dari hasil penelitian ini menunjukan bahwa lokasi usaha sangat menentukan kesuksesan usaha pada pedagang nasigoreng keliling diwilayah Tlogomas Kota Malang. Hal ini dapat terjadi karena berbagai faktor yang termasuk kedalam inikator lokasi usaha yaitu, pemilihan lokasi usaha yang mudah dijangkau dan dilalui jalur transportasi, pemilihan lokasi usaha yang berada di daerah keramaian seperti pada perempatan yang dekat pemukiman padat penduduk, dekat pusat perbelanjaan, pusat pendidikan dll, kemudian lokasi usaha berada di lingkungan yang aman, pemilihan lokasi yang tidak berdekatan dengan pesaing, serta lokasi usaha yang tidak melanggar 
peraturan pemerintah. Pedagang nasi goreng keliling diwilayah Tlogomas Malang dalam pemilihan lokasi juga diuntungkan dengan media berjualanya yaitu grobak dorong, yang memungkinkan pedagang bisa berpindah lokasi usaha secara leluasa dan dapat menjangkau lokasi yang tepat dan dekat dengan konsumen. Hasil penelitian ini mendukung hasil peneliti terdahulu oleh Indriyatni (2013) yang menyatakan faktor lokasi usaha berpengaruh positif dan signifikan terhadap keberhasilan usaha mikro dan kecil di wilayah Semarang Barat

\section{Pengaruh Kompetensi, Pembinaan, dan Lokasi Usaha terhadap Kesuksesan} Usaha.

Dari hasil penelitian dapat disimpulkan bahwa secara bersama-sama (simultan) kompetensi, pembinaan, lokasi usaha berpengaruh positif dan signifikan terhadap kesuksesan usaha.Terlihat nilai sig untuk kompetensi, pembinaan, lokasi usaha adalah 0,019. Nilai sig lebih besar dari nilai probabilitas 0,05 , atau $0,019<0,05$, Dengan kontribusi variabel kompetensi, pembinaan dan Lokasi usaha dalam menjelaskan variabel kesuksesan usaha sebesar. 18,9\% sedangkan $81,1 \%$ dijelaskan oleh variabel independen lainya. Maka $\mathrm{H}_{1}$ diterima dan Ho ditolak. Dengan pengaruh paling dominan dalah variabel Lokasi usaha yang memiliki pengaruh positif dan signifikan. Artinya para pedagang harus mempertahankan faktor-faktor pendorong kesiksesan usaha dari variabel Lokasi usaha karena pada variabel lokasi usaha memiliki pengaruh positif dan signifikan terhadap kesuksesan usaha, serta meningkatkan tingkat kompetensi agar dapat memeberi kontribusi positif dan signifikan, serta peran pembinaan sangat dibutuhkan agar kesuksesan usaha para pedagang nasi goreng keliling diwilayah Kelurahan Tlogomas dapat tercapai.

\section{SIMPULAN DAN SARAN}

Dari hasil penelitian menujukan kompetensi berpengaruh negatif dan tidak signifikan terhadap kesuksesan usaha pada pedagang nasi goreng keliling diwilayah Kelurahan Tlogomas Kota Malang. Pembinaan berpengaruh positif dan tidak signifikan terhadap kesuksesan usaha pada pedagang nasi goreng keliling diwilayah Kelurahan Tlogomas Kota Malang. lokasi usaha berpengaruh positif dan signifikan terhadap kesuksesan usaha pada pedagang nasi goreng keliling diwilayah Kelurahan Tlogomas 
Kota Malang. kompetensi, pembinaan, lokasi usaha berpengaruh positif dan signifikan terhadap kesuksesan usaha terhadap kesuksesan usaha pada pedagang nasi goreng keliling diwilayah Kelurahan Tlogomas Kota Malang.

Memperhatikan kondisi tersebut para pedagang hendaknya menambah pengetahuan tentang kompetensi wirausaha, seperti nagaimana mencari peluang, membat inovasi, mengikuti pelatihan - pelatihan agar potensi yang ada dapat dimanfaatkan secara optimal untuk mencapai kesuksesan usaha. Selain itu pemerintah dan dinas terkait hendaknya memberikan pembinaan lebih maksimal dan dengan pendekatan yang tepat agar dampak dari pembinaan lebih dirasakan oleh pedagang. Sedangkan untuk pemilihan lokasi usaha yang baik hendaknya dipertahankan oleh para pedagang karena memiliki dampak positif terhadap kesuksesan usaha.

\section{DAFTAR PUSTAKA}

Alhempi, Rudi, R. 2013. Pengaruh Pelatihan Dan Pembinaan Terhadap Pengembangan Usaha Kecil Pada Progranm Kemitraan Bina Lingkungan. Jurnal Media Bisnis dan Manajemen. Vol 13. No 1 Hal 20-38

Beck, T. 2007. Financing Constraints of SMEs in Developing Countries: Evidence, Determinants and Solutions. [Online]. http://arno.uvt.nl/show.cgi?fid=95654.

Busro,Muhamad. 2018. Teori-teori manajemen sumberdaya manusia. Cetakan pertama. Jakarta: Prenadamedia Group

Christiana, Yunyun. 2014. Pengaruh Kompetensi Wirausaha, Pembinaan Usaha, Dan Inovasi Produk Terhadap Perkembangan Usaha. Jurnal Of Sosial And Politic. Vol 5. Hal 1-10

Dongoran. F.R, 2016, Analisis Jumlah Pengangguran dan Ketenagakerjaan Terhadap Keberadaan Usaha Mikro Kecil dan Menengah Di Kota Medan, Jurnal Edu Tech, Vol 2 No. 2 hal. 59-72.

Ekasari, Nur. 2018. Pengaruh Lokasi Dan Kreatifitas Terhadap Keberhasilan Usaha Ukecil Mikro Menengah Dikawasan Wisata Gentala Arasy Kota Jambi. Jurnal Sains Sosio Humaniora. Vol 2. No 1 (2018)

Erliah. 2007. Pengaruh Persaingan, Promosi, Dan Keunikan Produk Terhadap Keberhasilan Usaha (Studi Pada Perajin Batik Desa Trusmi Kulon Kecamatan Plered Kabupaten Cirebon). Skripsi. UPI

Fithri, Prima. dan Amanda Febrina Sari, 2012. Analisis Kompetensi Kewirausahaan Industri Kecil Suku Cadang di Kota Padang, Optimasi Sistem Industri, Volume 11 Nomor 2, hal 280.

Fu'ad, N. 2015. Pengaruh Pemilihan Lokasi Usaha Terhadap Kesuksesan Usaha Mikro. Jurnal Media Ekonomi Dan Manajemen. Vol 30. No 1 (2015)

Hamalik, Oemar. 2000. Psikologi Belajar dan Mengajar. Bandung : Sinar Baru Al Gesindo. 
Indriyatni, Lies, 2013, Analisis Faktor Faktor Yang Berpengaruh Terhadap Keberhasilan Usaha Mikro Dan Kecil (Studi Pada Usaha Kecil Di Semarang Barat) Jurnal Stie Semarang, Vol. 5, No 1, hal. 54-70.

Irawati, R. 2018. Pengaruh Pelatihan Dan Pembinaan Terhadap Pengembangan Usaha Kecil. Jurnal JIBEKA. Vol 12. No 1. Hal 74-82

Kasali, R. 2005. Membangun kewirausahaan di Indonesia. 5ed. Manajemen Usahawan Indonesia.

Kasmir. 2006. Kewirausahaan. Jakarta: Raja Graffindo Persada

Kurniawan, A. 2018. Pengaruh Kompetensi Dan Kelanggengan Usaha Terhadap Keunggulan Bersaing. Jurnal Inspirasi Bisnis Dan Managemen. Vol 2. No 1. Hal 65-78

Lupiyoadi, Rambat. 2013. Manajemen Pemasaran Jasa. Edisi Ketiga. Jakarta: Salemba Maskan, M, 2018. Kewirausahaan .Malang: POLINEMA PRESS.

Meydianawathi, Luh G. 2011. Kajian Aktifitas Ekonomi Buruh Angkut Perempuan di Pasar Badung, Piramida Vol. 7 No. 1, hal. 20-27.

Pamela, P. 2016. Kompetensi Kewirausahaan Dengan Keberhasilan Usaha Peternak Sapi Pujon Malang. Jurnal Agribisnis Indonesia. Vol 4. No 1. Hal 57-66

Sayekti, Nugraheni S, 2016, Memberdayakan Pelaku Usaha Kecil Berbasispertanian : Studi Pada Kelompok Pengusaha Wanita Pelaku Usaha Tanaman Hias Pada Desa Sidomulyo Kota Batu, Jurnal Akuntansi, Vol. 1 No. 3 Hal. 245-264.

Suryana. 2011. Kewirausahaan pedoman Praktis: Kiat dan Proses Menuju Sukses. Jakarta: Salemba Empat.

Suyatno Purnama, Chamdan. 2010. Motivasi dan Kemampuan Usaha Dalam meningkatkan Keberhasilan Usaha Industri Kecil (Studi Pada Industri Kecil Sepatu di Jawa Timur). Jurnal Manajemen dan Kewirausahaan, pp. 177-184.

Tjiptono, Fandy. 2015. Strategi Pemasaran, Edisi 4, Penerbit Andi,. Yogyakarta.

Undang-undang Republik Indonesia. 1995. Nomor 9. Tentang Usaha Kecil. Diperoleh 29 oktober 2018. Dari http: //www.bi.go.id/id/tentang-bi/uu bi/Documents/UU20Tahun2008UMKM.pdf 